\title{
The role of prenatal ultrasound assessment in management of fetal cervicofacial tumors
}

\author{
Rafał Zieliński ${ }^{1}$, Maria Respondek-Liberska²
}

\author{
1Department of Pediatric Otorhinolaryngology, Medical University of Lodz, Lodz, \\ Poland \\ 2Department of Diagnosis and Prevention of Congenital Malformations, \\ Polish Mother's Memorial Hospital, Chair of Morphology and Embryology, \\ Medical University of Lodz, Lodz, Poland
}

Submitted: 5 September 2014

Accepted: 15 November 2014

Arch Med Sci 2016; 12, 4: 850-855

DOI: $10.5114 /$ aoms.2016.60972

Copyright $\odot 2016$ Termedia \& Banach

\begin{abstract}
Ultrasound prenatal examination enables one to assess the facial skeleton and the neck from the first weeks of gestation. Cervicofacial tumors detected via prenatal ultrasound are very rarely reported fetal pathologies. They include cystic hygromas, teratomas, epulides, vascular tumors, and thyroid tumors. The tumor category, its location and vascularization pattern allow one to accurately establish a diagnosis which is usually confirmed by clinical examination of the neonate or a pathological examination (surgical specimen, biopsy, autopsy). The prenatal ultrasound diagnosis of cervicofacial tumor in the fetus allows planning of pregnancy management and fetal therapy, preparation of the delivery, and perinatal as well as neonatal treatment.
\end{abstract}

Key words: prenatal, ultrasound, fetal, cervicofacial, tumor.

\section{Introduction}

Ultrasound assessment allows the facial skeleton and the neck of a fetus to be evaluated from the first trimester of pregnancy. However, the difficulties experienced in evaluating two-dimensional images and three-dimensional reconstructions result in fetal cervicofacial pathologies rarely being detected.

As these are rare anomalies, only a limited number of cases are typically reported by a single institution. Therefore, the newest information is of high value. The appearance of the fetal face changes in the course of pregnancy, and is associated with the deposition of fatty tissue, particularly in the region of the maxilla and cheeks. As the evaluation of the fetal face and the neck may present problems in the third trimester, due to the position of the fetus or location of the placenta on the anterior wall of the uterus being unfavorable, ultrasound assessment is usually most effective when performed prior to the $23^{\text {rd }}-24^{\text {th }}$ week of gestation. Two-dimensional ultrasonography performed by an experienced diagnostician is considered to be a very accurate tool in the assessment of prenatal fetal cervicofacial malformations [1].

$3 \mathrm{D}$ ultrasonography is of great value in visualizing the surfaces of the head and neck and presenting the results to parents or other physicians involved in the care of neonates and infants [2]. Sharing this information

\author{
Corresponding author: \\ Rafał Zieliński MD \\ Department of \\ Pediatric Otorhinolaryngology \\ Medical University of Lodz \\ 36/50 Sporna St \\ 91-738 Lodz, Poland \\ Phone/fax: +48 426177720 \\ E-mail: rafal.zielinski@umed. \\ lodz.pl
}


is especially important as cervicofacial tumors may compromise the upper airways, thus affecting the planning of in utero and perinatal treatment. Other methods such as magnetic resonance imaging (MRI) and fetoscopy may also be helpful in diagnosing pathologies resulting in upper airway patency in the fetus [3, 4].

Sonographic assessment allows a precise diagnosis to be established based on tumor category, location and vascularization pattern. However, the approach is much more difficult than a newborn evaluation or pathological study of a fetus, and differential diagnosis should be taken into consideration [5].

\section{Fetal cervicofacial tumors in prenatal ultrasound assessment}

Cystic hygromas are fetal tumors occurring within the neck region [6] which can be described as bilateral hypoechogenic cyst-like cavities under ultrasound examination. They are best visualized in the coronal plane and may be detected as early as at the end of the first trimester of pregnancy [7]. The presence of septations within the tumor may indicate the coexistence of aneuploidy [8]. In cystic hygromas, a tendency towards regression can be observed in up to $10 \%$ of cases (Figure 1).

Other tumors detected by ultrasound examination of the fetal head and neck include lymphatic-venous malformations, lymphangiomas and hemangiomas. Although lymphatic-venous malformations are rare, they do not tend to demonstrate spontaneous involution during the first year of a child's life. Prenatal ultrasound identifies them as cystic tumors with multiple thin septations. Glossal lymphangiomas are also rarely found: ultrasound examination reveals solid or hyperechogenic tumors growing within the oral cavity. These anomalies seldom extend beyond their initial locations.

Large hemangiomas are detected by prenatal ultrasound examination in the region of the face, occiput and neck. They are characterized by rich, occasionally heavily calcified, vascularization [9]. These tumors may be a component of Kasabach-Merritt syndrome. Severe thrombocytopenia, a life-threatening condition to a fetus or a neonate, accompanies the occurrence of these hemangiomas [10].

Among other pathologies, richly vascularized tumors such as vascular lesions can significantly impair the cardiovascular system of the fetus, causing congestive heart failure [11, 12]. Unfortunately, no data exist concerning the problem in cases of cervicofacial tumors.

Epulis (Neumann's tumor), gingival pyogenic granuloma, is a benign abnormality most frequently originating from the maxillary gingiva. It is characterized by slow growth and is typically recognized as late as in the third trimester of pregnancy. Prenatal ultrasonography reveals it to be a solid tumor with poor vascularization (Figure 2).

Epignathus is a very rare teratoma which develops within the oral cavity and the throat. It occasionally projects into the nasal cavity and the anterior cranial fossa. Histopathologically, it is most frequently a non-malignant tumor. However, there are some reports on partially malignant texture [13]. Epignathus frequently arises from the sphenoid bone, hard or soft palate, pharynx, tongue or mandible. Ultrasound assessment allows a solid tumor of the oral cavity with elements of cysts and calcifications to be identified. In such cases, a detailed evaluation of the brain is necessary because the tumor can grow intracranially, resulting in hydrocephalus. Another oral cavity neoplasm occurring in the fetus is myoblastoma (Abrikosov's tumor), a rare non-malignant anomaly developing only in the oral cavity of female fetuses. On ultrasound examination, it presents as a solid tumor attached to the oral cavity floor.

Prenatal ultrasound scanning is also a reliable method of detecting superficial cervicofacial teratomas and thyroid tumors. Teratomas are typically solid hyperechogenic masses with the likely occurrence of cystic hypoechogenic spaces and calcification foci.
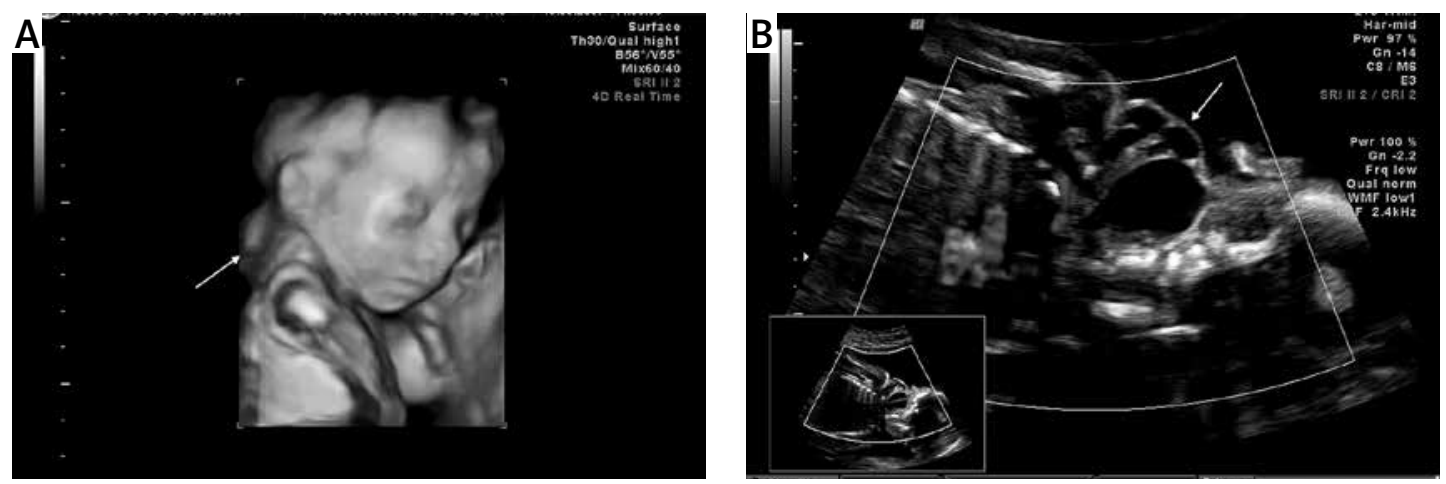

Figure 1. Cystic hygroma of the neck in the fetus at 22 weeks' gestation. A - 3D ultrasound scan of the fetal head and neck. B-2D ultrasound of the fetal head and neck, frontal plane 

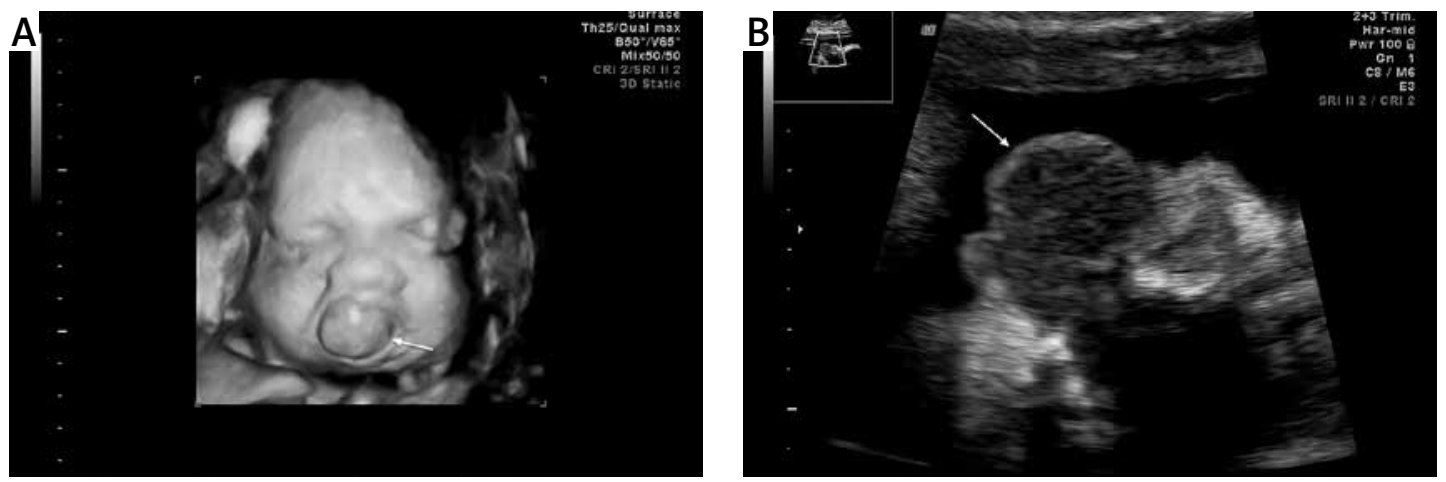

Figure 2. Epulis in the fetus at 36 weeks' gestation. A - 3D ultrasound scan of the fetal head. B - 2D ultrasound scan of the fetal head, sagittal plane
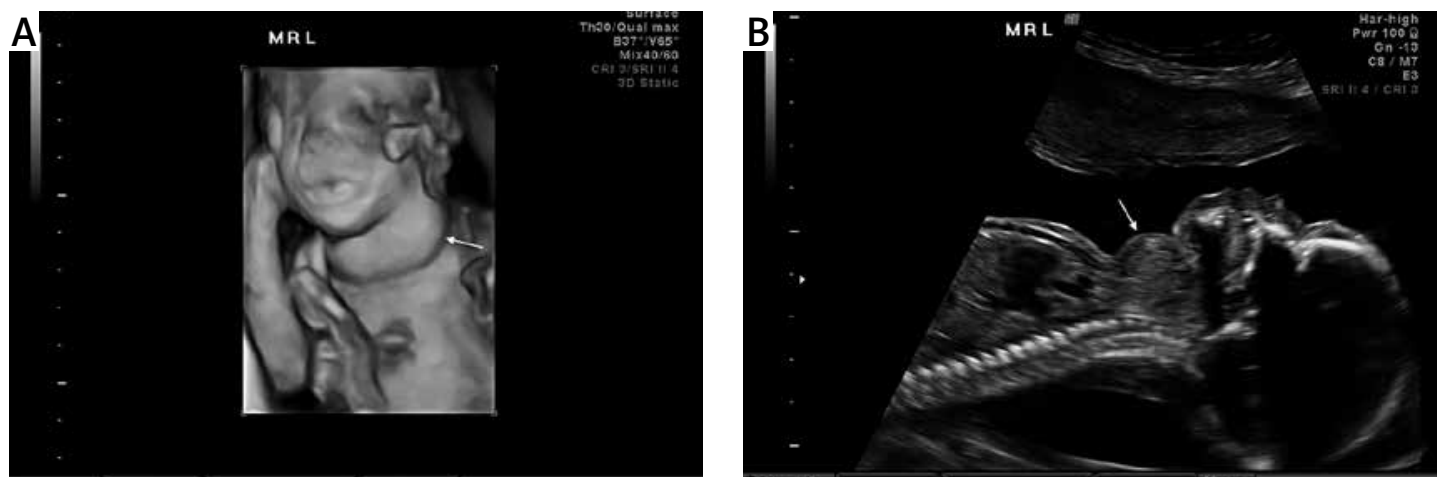

Figure 3. Goiter in the fetus at 22 weeks' gestation. A - 3D ultrasound scan of the fetal head and neck. B - 2D ultrasound scan of the fetal head and neck, sagittal plane

On prenatal ultrasound examination, thyroid tumors are well-isolated hyperechogenic tumors connected with the gland. Prenatal ultrasound color Doppler examination may reveal increased vascularity; however, discriminating between fetal hypothyroidism and hyperthyroidism based only on ultrasound may be difficult. Fetal tachycardia is known to be a good indicator of hyperthyroidism. Delayed bone maturation is a specific feature in fetuses with hypothyroid goiters [14]. The occurrence of goiter in the fetus in subsequent gestations has also been documented [15] (Figure 3).

Other hyperechogenic tumors within the fetal head and neck, such as rhabdomyoma and rhabdomyosarcoma, have also occasionally been described [16] (Tables I and II).

\section{In utero treatment, gestation planning and postnatal treatment in cases of prenatally diagnosed fetal cervicofacial tumors}

Initial reports suggest the possibility of in utero removal of fetal cervicofacial tumors. Removal of tumors in utero has already been employed in the treatment of fetal malformations in other localizations, such as teratomas in the sacrococcygeal region $[17,18]$. The first successful intrauterine removal of a fetal cervicofacial tumor was performed by Kontopoulos et al., University of Miami/ Jackson Memorial Hospital, in 2012 [3].
When the tumor mass is large, impaired swallowing of amniotic fluid may additionally occur, resulting in polyhydramnios at the beginning of the third trimester of pregnancy. Amniodrainage is used to relieve maternal discomfort in cases of polyhydramnios and to prevent the complications associated with increased intrauterine pressure, such us preterm labor, premature rupture of membranes (PROM) and fetal hypoxia [19].

Fetal goiters may accompany mother hypothyroidism and are occasionally induced by propylthiouracil treatment during pregnancy. Some studies report good outcomes of fetal goiter treatment after intra-amniotic injections of levothyroxine [20].

In cases that carry a poor prognosis for the affected fetus due to the presence of the tumor or confirmed chromosomal defects before the $24^{\text {th }}$ week of gestation, termination of pregnancy can be considered, especially when other defects concomitant with cervicofacial tumors of the fetus are diagnosed [21].

A considerable proportion of cervicofacial tumors demonstrate a tendency for postnatal idiopathic regression. Therefore, in cases which do not indicate any need for urgent surgery due to malignancy, large deformations caused by the tumor (torticollis, sternocleidomastoid muscle hypoplasia) or impairment of swallowing and breathing, the treatment of choice is to observe the tumors. If no 
Table I. The list of articles identified in Medline concerning fetal cervicofacial tumors detected in prenatal ultrasound examination (years 2003-2012)

\begin{tabular}{|c|c|c|c|c|}
\hline $\begin{array}{l}\text { Author's } \\
\text { name }\end{array}$ & $\begin{array}{l}\text { Publication } \\
\text { year }\end{array}$ & $\begin{array}{l}\text { Gestational } \\
\text { age [weeks] }\end{array}$ & Tumor type & Treatment and the fetus history \\
\hline Kornacki & 2012 & 29 & Fetal goiter & $\begin{array}{l}\text { Cesarean section at the } 29^{\text {th }} \text { week of gestation. Newborn } \\
\text { died after birth. For the next pregnancy, ultrasound prena- } \\
\text { tal examination, performed at week } 19 \text {, revealed fetal goi- } \\
\text { ter. Intra-amniotic levothyroxine pharmacotherapy. Cesare- } \\
\text { an section at the } 37^{\text {th }} \text { week of gestation. Child euthyroid. } \\
\text { Normal growth and development }\end{array}$ \\
\hline Ince & 2012 & 33 & $\begin{array}{l}\text { Malignant } \\
\text { epignathus }\end{array}$ & $\begin{array}{l}\text { Cesarean section at the } 33^{\text {rd }} \text { week of gestation. Emergency } \\
\text { tracheostomy. Partial excision of the tumor on the second } \\
\text { day. Second operation with total excision of the tumor on } \\
50^{\text {th }} \text { day of life. Discharged from hospital with tracheosto- } \\
\text { my and gastrostomy }\end{array}$ \\
\hline Forys & 2010 & 37 & Epulis & $\begin{array}{l}\text { Cesarean section at the } 37^{\text {th }} \text { week of gestation. EXIT proce- } \\
\text { dure and tumor excision. Normal growth and development }\end{array}$ \\
\hline Clay & 2009 & 32 & $\begin{array}{l}\text { Cervical } \\
\text { hemangioma }\end{array}$ & $\begin{array}{l}\text { Cesarean section at the } 35^{\text {th }} \text { week of gestation. Postnatal } \\
\text { pharmacotherapy. Scar observed, otherwise normal growth } \\
\text { and development }\end{array}$ \\
\hline Johnson & 2009 & 25 & $\begin{array}{l}\text { Cervical } \\
\text { teratoma }\end{array}$ & $\begin{array}{l}\text { Cesarean section at the } 37^{\text {th }} \text { week of gestation. EXIT proce- } \\
\text { dure. Newborn died after birth }\end{array}$ \\
\hline Mikovic & 2009 & 21 and 23 & $\begin{array}{l}\text { Two cases } \\
\text { of cystic } \\
\text { hygroma }\end{array}$ & $\begin{array}{l}\text { Intrauterine OK-432 in tumor injection. Delivery at the } 39^{\text {th }} \\
\text { week of gestation (delivered vaginally) and the } 40^{\text {th }} \text { week } \\
\text { of gestation (Cesarean section). Normal growth and devel- } \\
\text { opment in both children }\end{array}$ \\
\hline Dar & 2009 & 12 & Epignathus & Pregnancy termination at the $13^{\text {th }}$ week of gestation \\
\hline Antinolo & 2009 & 21 & Epignathus & $\begin{array}{l}\text { Twin pregnancy. Other fetus normal. Cesarean section at } \\
\text { the } 33^{\text {rd }} \text { week of gestation. EXIT procedure and tumor exci- } \\
\text { sion with reconstruction. No follow-up data }\end{array}$ \\
\hline Lassen & 2008 & 31 & Fetal goiter & $\begin{array}{l}\text { Intra-amniotic levothyroxine pharmacotherapy. Cesarean } \\
\text { section at the } 40^{\text {th }} \text { week of gestation. Normal growth and } \\
\text { development }\end{array}$ \\
\hline Araujo Jr & 2007 & 15 & $\begin{array}{l}\text { Cervicofacial } \\
\text { teratoma }\end{array}$ & $\begin{array}{l}\text { Cesarean section at the } 32^{\text {nd }} \text { week of gestation. Orotrache- } \\
\text { al intubation and observation }\end{array}$ \\
\hline Phupong & 2007 & 13 & $\begin{array}{c}\text { Cystic } \\
\text { hygroma }\end{array}$ & $\begin{array}{l}\text { Spontaneous resolution. Delivery at the } 40^{\text {th }} \text { week of ges- } \\
\text { tation. } 47 X Y Y \text { karyotype, otherwise normal growth and de- } \\
\text { velopment }\end{array}$ \\
\hline Valdez & 2006 & 24 & $\begin{array}{l}\text { Cervicofacial } \\
\text { rhabdomyoma }\end{array}$ & $\begin{array}{l}\text { Cesarean section at the } 38^{\text {th }} \text { week of gestation. Intubation } \\
\text { and postnatal tumor excision. Recurrence of the lesion } \\
14 \text { months after the first surgery and repeated excision of } \\
\text { the lesion. Four-year follow-up without recurrence. Normal } \\
\text { growth and development }\end{array}$ \\
\hline Yoshida & 2006 & 35.5 & $\begin{array}{c}\text { Cervical } \\
\text { hemangioma }\end{array}$ & $\begin{array}{l}\text { Cesarean section at the } 35^{\text {th }} \text { week of gestation. EXIT pro- } \\
\text { cedure. Postnatal laser therapy, pharmacotherapy. Scar ob- } \\
\text { served, otherwise normal growth and development }\end{array}$ \\
\hline Paladini & 2005 & 21 & $\begin{array}{c}\text { Cystic } \\
\text { hygroma }\end{array}$ & Termination at the $22^{\text {nd }}$ week of gestation \\
\hline Sasaki & 2003 & 25 & $\begin{array}{c}\text { Cystic } \\
\text { hygroma }\end{array}$ & $\begin{array}{l}\text { Intrauterine OK-432 injection in tumor. Delivery at the } 38^{\text {th }} \\
\text { week of gestation. Normal growth and development }\end{array}$ \\
\hline
\end{tabular}

regression is observed, a surgical procedure, postnatal surgery involving tumor resection combined with simultaneous reconstructive procedures, is considered in the first year of life of the child [22]. Treatment of cystic hygromas and vascular malformations involves tumor resection or sclerotherapy with picibanil preparation (OK-432 - also in utero therapy) and local steroid therapy [23].
Surgical removal of hemangiomas is currently only rarely performed. The implementation of non-selective $\beta$-blockers such as propranolol and acebutolol has changed the management in the case of juvenile hemangiomas and improved postnatal prognosis. The treatment usually lasts until the end of the first year of life, i.e. until the time of tumor involution [24]. 
Table II. Fetal cervicofacial tumors. Differential diagnoses by ultrasound and color Doppler

\begin{tabular}{|c|c|}
\hline Cervicofacial tumors & Ultrasound characteristics \\
\hline Cystic hygroma & $\begin{array}{c}\text { Solid tumor. Frequent location within the tongue and the cervical region. The presence } \\
\text { of septations may suggest chromosomal defects }\end{array}$ \\
\hline Teratoma & $\begin{array}{c}\text { Solid tumor, occasionally with cystic elements and calcifications in different areas, } \\
\text { frequently within the oral cavity and the pharynx }\end{array}$ \\
\hline Epulis & Solid tumor with poor vascularization localized within the oral vestibule \\
\hline Vascular malformation & Cystic tumor with multiple thin septations. Color Doppler would show vascularization \\
\hline Hemangioma & Well-isolated tumor, increased blood flow in Doppler examination \\
\hline Myoblastoma & Solid tumor. Frequent localization within the oral cavity \\
\hline Thyroid tumor & $\begin{array}{l}\text { Cervical solid tumor. Well isolated, connected with the thyroid gland, may present with } \\
\text { increased vascularization }\end{array}$ \\
\hline
\end{tabular}

\section{Perinatal airway management in neonates and outcomes in cases of prenatally diagnosed fetal cervicofacial tumors}

At the last stage of pregnancy, the size of the pathological structure is of great significance. Fetal morphological defects such as tumors exceeding $50 \mathrm{~mm}$ are regarded as an indication for delivery by cesarean section [25]. Tumors that obstruct the respiratory tract at the level of the upper, middle or lower pharynx, larynx or trachea, either completely or to a great extent, can lead to congenital high-airway obstruction syndrome (CHAOS). In such situations, two possibilities are taken into consideration during perinatal management, with delivery by cesarean section being recommended for neonates.

In the case of airway obstruction, the EXIT procedure, ex-utero intrapartum treatment, is considered. Following the cesarean section, intraoperative ultrasound is performed at the suprapubic region to determine the attachment of the placenta. The attachment of the placenta can be determined clearly before the operation. A hysterotomy is then carried out to reveal the fetal head. The newborn is intubated and its condition is monitored. Next, the umbilical cord is clamped. If intubation is unsuccessful, urgent tracheotomy and possible tumor surgery are considered [26-28].

Although in utero therapy and perinatal treatment may considerably improve the chance of survival of fetuses with cervicofacial pathologies, the typical survival rate is poor. Such prenatal risks as hydramnios, preterm birth possibility, PROM, abnormal karyotype, and combined and complex abnormalities worsen the prognosis [29]. According to Kamil et al., considerably higher mortality rates are observed for head and neck fetal tumors and sacrococcygeal tumors than tumors of other locations, the respective rates being $52.6 \%$ and $33.3 \%$. Mortality rates are also considerably higher in cases of teratoma. The presence of hydrops fetalis independently predicted an unfavorable outcome in most cases of fetal tumors [5].

Prenatal ultrasound examination provides the necessary information regarding the pathology of the head and neck, including tumors. The presence of a neoplasm as well as its topography in relation to other structures, including the airway, and large cervical vessels can be identified, which allows perinatal care and subsequent procedures to be planned. Cervicofacial tumors identified during fetal life represent not only a diagnostic but also a therapeutic challenge for pediatric specialists. Knowledge of the presence of a tumor obstructing or compressing the upper respiratory tract is extremely important for perinatal care and planning to secure the airway of the neonate. Therefore, greater cooperation should be encouraged between diagnosticians performing the ultrasound assessments of the fetal head and neck, and the pediatric laryngologists, surgeons and anesthetists responsible for the child in the perinatal, neonatal and infantile periods [30].

\section{Conflict of interest}

The authors declare no conflict of interest.

\section{References}

1. Rotten D, Levaillant JM. Two- and three-dimensional sonographic assessment of the fetal face. 1 . A systematic analysis of the normal face. Ultrasound Obstet Gynecol 2004; 23: 224-31.

2. Avni FE, Cos T, Cassart M, et al. Evolution of fetal ultrasonography. Eur Radiol 2007; 17: 419-31.

3. Kontopoulos EV, Gualtieri M, Quintero RA. Successful in utero treatment of an oral teratoma via operative fetoscopy: case report and review of the literature. Am J Obstet Gynecol 2012; 207: e12-5.

4. Shih JC, Hsu WC, Chou HC, et al. Prenatal three-dimensional ultrasound and magnetic resonance imaging evaluation of a fetal oral tumor in preparation for the ex-utero intrapartum treatment (EXIT) procedure. Ultrasound Obstet Gynecol 2005; 25: 76-9; discussion 79. 
5. Kamil D, Tepelmann J, Berg C, et al. Spectrum and outcome of prenatally diagnosed fetal tumors. Ultrasound Obstet Gynecol 2008; 31: 296-302.

6. Ganapathy R, Guven M, Sethna F, Vivekananda U, Thilaganathan B. Natural history and outcome of prenatally diagnosed cystic hygroma. Prenat Diagn 2004; 24: 965-8.

7. Bekker MN, Haak MC, Rekoert-Hollander M, Twisk J, Van Vugt JM. Increased nuchal translucency and distended jugular lymphatic sacs on first-trimester ultrasound. Ultrasound Obstet Gynecol 2005; 25: 239-45.

8. Bronshtein M, Bar-Hava I, Bejar J, Toder V, Blumenfeld Z. The difference between septated and nonseptated nuchal cystic hygroma in the early second trimester. Obstet Gynecol 1993; 81: 683-7.

9. Kaplan MC, Coleman BG, Shaylor SD, et al. Sonographic features of rare posterior fetal neck masses of vascular origin. J Ultrasound Med 2013; 32: 873-80.

10. Respondek-Liberska M, Janiak K, Jakubek A, et al. Prenatal diagnosis of fetal face hemangioma in a case of Kasabach-Merritt syndrome. Ultrasound Obstet Gynecol 2002; 19: 627-9.

11. Fadler KM, Askin DF. Sacrococcygeal teratoma in the newborn: a case study of prenatal management and clinical intervention. Neonatal Netw 2008; 27: 185-91.

12. Zong L, Wang L, Huang P, Shao W, Song Y, Gou W. High temperature requirement $A 1$ in placental tissues and serum from pre-eclamptic pregnancies with or without fetal growth restriction. Arch Med Sci 2013; 9: 690-6.

13. Ince EZ, Cekmez F, Yildirim S, et al. Malignant epignathus including a nephroblastoma component and successful management. Ann Diagn Pathol 2013; 17: 288-90.

14. Huel C, Guibourdenche E, Vuillard E, et al. Use of ultrasound to distinguish between fetal hyperthyroidism and hypothyroidism on discovery of a goiter. Ultrasound Obstet Gynecol 2009; 33: 412-20.

15. Kornacki J, Mrozinski B, Skrzypczak J. A rare case of recurrent fetal goiter. Fetal Diagn Ther 2012; 31: 69-72.

16. Valdez TA, Desai U, Volk MS. Recurrent fetal rhabdomyoma of the head and neck. Int J Pediatr Otorhinolaryngol 2006; 70: 1115-8.

17. Hirose S, Farmer DL. Fetal surgery for sacrococcygeal teratoma. Clin Perinatol 2003; 30: 493-506.

18. Wilson RD. Prenatal evaluation for fetal surgery. Curr Opin Obstet Gynecol 2002; 14: 187-93.

19. Leung WC, Jouannic JM, Hyett J, Rodeck C, Jauniaux E. Procedure-related complications of rapid amniodrainage in the treatment of polyhydramnios. Ultrasound Obstet Gynecol 2004; 23: 154-8.

20. Stevenson RE, Hall J. Index to tables of malformations and associated syndromes. In: Human Malformations And Related Anomalies. Stevenson RE, Hall J (eds). Oxford University Press, Oxford 2006; 1473-7.

21. Kosmaidou-Aravidou Z, Siabalioti G, Karpathios S, Grigori P, Panani A. Prenatal diagnosis of a cervical teratoma with a cytogenetic study. J Matern Fetal Neonatal Med 2006; 19: 377-9.

22. Kobayashi S, Tanaka M, Ohashi Y, Tanaka Y, Maegawa J. Functional reconstruction of epignathus with cleft palate using part of a mature teratoma. Cleft Palate Craniofac J 2012; 49: e69-74.

23. Mitsukawa N, Satoh K. New treatment for cystic lymphangiomas of the face and neck: cyst wall rupture and cyst aspiration combined with sclerotherapy. J Craniofac Surg 2012; 23: 1117-9.

24. Blanchet C, Nicollas R, Bigorre M, Amedro P, Mondain M. Management of infantile subglottic hemangioma: acebutolol or propranolol? Int J Pediatr Otorhinolaryngol 2010; 74: 959-61.
25. Yu JA, Sohaey R, Kennedy AM, Selden NR. Terminal myelocystocele and sacrococcygeal teratoma: a comparison of fetal ultrasound presentation and perinatal risk. ANJR Am J Neuroradiol 2007; 28: 1058-60.

26. Lim FY, Crombleholme TM, Hedrick HL, et al. Congenital high airway obstruction syndrome: natural history and management. J Pediatr Surg 2003; 38: 940-5.

27. Bouchard S, Johnson MP, Flake AW, et al. The EXIT procedure: experience and outcome in 31 cases. J Pediatr Surg 2002; 37: 418-26.

28. Hirose $S$, Harrison MR. The ex utero intrapartum treatment (EXIT) procedure. Semin Neonatol 2003; 8: 207-14.

29. Anderson NG, Kennedy JC. Prognosis in fetal cystic hygroma. Aust N Z J Obstet Gynaecol 1992; 32: 36-9.

30. Chen YL, Wu KH. Airway management of patients with craniofacial abnormalities: 10-year experience at a teaching hospital in Taiwan. J Chin Med Assoc 2009; 72: $468-70$ 